\title{
Effects of High-Performance Work Systems (HPWS) on Hospitality Employees' Outcomes through Their Organizational Commitment, Motivation, and Job Satisfaction
}

\author{
Daniel Dorta-Afonso 1,*(D), Manuel González-de-la-Rosa ${ }^{2}$, Francisco J. García-Rodríguez ${ }^{2}$ \\ and Laura Romero-Domínguez ${ }^{1}$ \\ 1 Department of Economics and Business Management, Universidad de Las Palmas de Gran Canaria, \\ 35017 Las Palmas, Spain; laura.romero@ulpgc.es \\ 2 Department of Business Management and Economic History, La Laguna University, \\ 38200 Santa Cruz de Tenerife, Spain; mgonzale@ull.edu.es (M.G.-d.-l.-R.); fgarciar@ull.edu.es (F.J.G.-R.) \\ * Correspondence: Daniel.dorta@ulpgc.es
}

Citation: Dorta-Afonso, D.; González-de-la-Rosa, M.; García-Rodríguez, F.J.;

Romero-Domínguez, L. Effects of High-Performance Work Systems (HPWS) on Hospitality Employees' Outcomes through Their

Organizational Commitment,

Motivation, and Job Satisfaction. Sustainability 2021, 13, 3226. https:// doi.org/10.3390/su13063226

Academic Editors: Huseyin Arasli, Trude Furunes and Hasan Evrim Arici

Received: 24 February 2021

Accepted: 12 March 2021

Published: 15 March 2021

Publisher's Note: MDPI stays neutral with regard to jurisdictional claims in published maps and institutional affiliations.

Copyright: (c) 2021 by the authors. Licensee MDPI, Basel, Switzerland. This article is an open access article distributed under the terms and conditions of the Creative Commons Attribution (CC BY) license (https:/ / creativecommons.org/licenses/by/ $4.0 /)$.

\begin{abstract}
The purpose of this research is to examine the underlying mechanisms inside the so-called black box that relate high performance work systems (HPWS) with employees' well-being and job performance in hospitality. We surveyed a sample of 494 hotel workers to test a research model that related the following variables: HPWS, organizational commitment, motivation, job satisfaction, quality of life (QoL), and individual job performance. Structural equation modelling, namely through PLS-SEM, was conducted. We confirmed that HPWS directly influence employees' motivation, organizational commitment, job satisfaction, and QoL. Additionally, workers' motivation and organizational commitment positively influence job satisfaction, which, in turn, enhances workers' QoL. Moreover, job satisfaction and quality of life significantly predicted individual job performance. This study contributes to unlocking the so-called black box relating HPWS with job outcomes as well as to the growing body of research that relates employees' well-being with performance. From a managerial point of view, hospitality firms should prioritize investment in HPWS, as its design and implementation affects employees' attitudes and behaviors. Future lines of research should consider bundles of practices instead of the whole HPWS effects on employees' attitudes and behaviors.
\end{abstract}

Keywords: high performance work systems (HPWS); human resources management; employees' motivation; organizational commitment; job satisfaction; quality of life

\section{Introduction}

The worldwide outbreak of COVID-19 has brought the world to a standstill, and tourism has been the worst affected of all major economic sectors [1]. Its impact on this labor-intensive industry [2], characterized by high interpersonal interactions [3], is incalculable, threatening the survival of organizations and destroying a huge number of jobs [4]. The tourism sector is known for its resilience to economic downturns and crises, and may bounce back quickly [5]. Rebuilding better in the post-pandemic period, after experiencing zero tourism, will require aligning the industry more closely with Sustainable Development Goal 8: "promote sustained, inclusive, and sustainable economic growth, full and productive employment, and decent work for all" [6].

Employees are often viewed as one of the most important assets in hospitality organizations due to their critical role for service quality, tourist satisfaction, and organizational performance [7-11]. Therefore, the promotion of decent work should be a priority in the human resources management (HRM) strategies of tourism organizations [12], as it is essential for employees' motivation, commitment, and job satisfaction, as well as the quality of tourism services and the improvement of organizational productivity [2]. However, the "dark side of the coin" in the touristic workplace has traditionally been low wages, 
reduced security and stability, high levels of turnover, limited opportunities for professional development, and non-social working hours [13-15]. Workers' needs are often not met [16], resulting in low levels of well-being. Consequently, hoteliers should focus efforts on providing employees with proper labor conditions and working environments in which they can maximize their individual performance.

In this research, we argue that through high-performance work systems (HPWS, hereinafter) hotels can enhance employees' well-being, which will, in turn, improve individual job performance. HPWS are defined as systems of interrelated unique HRM practices intended to enhance workers' skills, participation, and effort [17-19]. These practices include internal mobility, training, results-oriented appraisals, employment security, participation, work-life balance, and clear job description [20]. Their impact on employees' outcomes and firms' performance has caught the attention of researchers and practitioners for decades in general business [21-23] and in the hospitality and tourism industry [18,24,25]. Concretely, in the lodgment industry, findings to date highlight the positive impact of HPWS on several positive outcomes such as hotel performance [26].

Despite the well-documented relationship between HPWS and outcomes, "the mechanisms underlying this relationship remain a black box" [18]. In essence, there is consensus on their positive repercussions, but little is known about how their effects take place $[17,19,27-29]$. In this sense, several studies have empirically verified the mediational roles of employees' citizenship behaviors [18], effort [29], organizational commitment $[17,22]$, work engagement $[30,31]$, and job satisfaction $[17,23]$.

Due to the importance of HPWS in the hospitality and tourism industry [32], scholars highlight the need for further investigation on the topic $[27,28]$, especially in hotel settings [19]. Thus, in this research, we build on the identified gaps in the literature to seek ways of opening the so-called black box between HPWS and outcomes, focusing on the hotel sector. Concretely, we investigate the mechanisms that relate employees' perceptions of the use of HPWS with their well-being. In addition, we empirically corroborate the relationship between workers' well-being and individual job performance.

In particular, we focus here on two main indicators of employee well-being conducive for organizational outcomes, that is, job satisfaction [33] and quality of life [34]. Job satisfaction indicates the extent to which a person likes their job [35], and quality of life (QoL) goes further than job satisfaction, implying the degree to which a person is satisfied with their life as a whole [36]. Furthermore, employees' well-being brings up a number of conceptually different but related constructs, such as motivation and organizational commitment. There is evidence that HPWS can directly enhance employees' overall QoL [36], job satisfaction [37], motivation [38], and organizational commitment [39]. Moreover, job satisfaction is one of the main determinants of QoL [40,41], and workers' motivation and organizational commitment have been acknowledged as main determinants of job satisfaction $[42,43]$. Thus, it is reasonable to expect that HPWS can positively affect QoL through the causal chains that go from workers' motivation and organizational commitment to job satisfaction.

Building on previous literature, we have designed a study to analyze the subjacent mechanisms through which HPWS affect QoL. Specifically, we investigate the paths through motivation and organizational commitment from HPWS to job satisfaction and QoL. In addition, we explore the effects of employees' job satisfaction and QoL on individual performance.

This research provides the field with manifold theoretical as well as managerial contributions. First, we answer recent calls in the literature remarking on the lack of empirical studies in the hospitality and tourism sector, analyzing the effects of HPWS on employees' outcomes $[19,27]$. In doing so, we contribute to the burgeoning research stream that supports the benefits of employees' perceptions of HPWS on results such as QoL $[18,19,27,32]$. Second, we contribute to filling the evident research gap concerning the underlying mechanisms within the so-called black-box through which HPWS affect outcomes [18]. This is a noteworthy contribution, as scholars have stated the need to 
further investigate variables, such as motivation and organizational commitment, through which HPWS can impact employees' attitudes and behaviors [44-46]. Third, we place job satisfaction and QoL as predictors of individual job performance. As a result, we provide managerial recommendations for hoteliers to implement HPWS given their impact on employees' well-being and performance.

This paper is organized as follows. After this introduction, we present the theoretical framework that supports our research hypotheses. Then, we introduce our methodological approach and report our empirical results. We conclude with a discussion in which we reflect on the main implications of our study and suggest future lines of inquiry.

\section{Theoretical Framework and Hypotheses}

\subsection{HPWS Effects on Workers' Quality of Life}

QoL refers to a general level of satisfaction with life as a whole and includes cognitive and affective concerns about family satisfaction, job satisfaction, and leisure satisfaction, among other life domain satisfactions [36]. The bottom-up frame is the most popular theory to explain QoL, and it is based on the premise that individual QoL is placed at the top of a satisfaction hierarchy resulting from the satisfaction with all life domains of a person [47]. Thus, overall QoL is directly impacted by satisfaction with one's family, work, health, free time, and relationships among others. Research in hospitality and tourism settings has proved that QoL significantly and directly impacts employee turnover [48] and business performance [34]. Therefore, enhancing QoL may be the key for the traditional problem of hospitality organizations to retain employees in an industry characterized by unsocial working hours, low pay, and lack of career development [49].

There is evidence that the range of HRM practices comprising HPWS can enhance employees' overall QoL. For example, in a study focused on multinational companies in Malaysia, it was found that work environment (e.g., teamwork and organizational structure) and job facets (e.g., participation and job enrichment) greatly determined overall QoL [50]. Such findings suggest that through the introduction and improvement of HPWS, organizations can enhance workers' QoL and both increase productivity and reduce employee turnover. Other research among frontline employees in the tourism industry found work-life balance and leisure compensation systems directly impacted workers' QoL [36]. These findings are further supported with similar evidence from hotel workers in Jordan [48]. Likewise, an empirical study with hotel workers in China found that job characteristics such as task significance directly impacted employees' QoL [3]. Overall, extant literature suggests that organizational efforts to support employees [41] and build long-term relationships satisfying their various needs [47] are determinants of QoL. Previous research has focused on unique practices, but evidence suggests that aggregated systems of HRM practices (i.e., HPWS) can directly enhance employees' QoL. Consequently, we formally predict:

\section{Hypothesis 1: HPWS positively affect hospitality employees' QoL.}

\subsection{The Role of Job Satisfaction between HPWS and QoL}

Job satisfaction refers to the extent to which people like or dislike their position, constituting a worker's attitude on how good they feel about their jobs and their positive feeling towards their roles within organizations [35]. It has been widely acknowledged as one of the main determinants of workers' behaviors [51]. For example, job satisfaction reduces workers' deviant behaviors [52], absenteeism [53], and turnover [43,54].

Therefore, hoteliers need to focus efforts on enhancing employees' job satisfaction. To do so, and as clearly highlighted in a recent meta-analysis, workers' job satisfaction can be improved on the basis of effective organizational management practices [55]. Consequently, HPWS may positively affect the workforce's level of job satisfaction. This is because extant literature points out that employees value HRM practices comprising HPWS such as work-life balance [49,56], rewards [57], job security [58], or training opportunities [37,57]. 
Furthermore, some evidence also supports the positive repercussions of whole systems of high-performance work practices on job satisfaction $[17,23]$.

In addition, existing studies provide confirmation that job satisfaction predicts QoL [40] or that it mediates the relationship between job-related characteristics and QoL [59]. Similar findings also hold true in the hospitality and tourism sector [3,41,47]. The main reason behind these conclusions is that by definition QoL implies satisfaction with all life domains including satisfaction with one's own job [36]. Given this circumstance, it is reasonable to expect that HPWS can enhance QoL by prompting higher levels of job satisfaction. Consequently, we hypothesize that:

Hypothesis 2: HPWS positively affects hospitality employees' job satisfaction (a), which will, in turn, enhance their overall QoL (b).

\subsection{HPWS, Workers' Motivation, and Job Satisfaction}

Motivation refers to the arousal, direction, and persistence to voluntarily carry out actions with a goal [60]. Thus, work motivation refers to the allocation of personal effort to perform work-related actions. It has been a central issue in hospitality due to the difficulties in attracting and retaining the most talented employees, which can be assessed through enhancing employees' motivation [38]. Moreover, empirical evidence supports that highly motivated employees are beneficial for organizational performance in hospitality and tourism enterprises [61]. Thus, motivating the workforce is of crucial importance for managers.

Employees can be effectively motivated to perform well in their roles both extrinsically and intrinsically $[62,63]$. Whereas the former implies performing behaviors because of their perceived usefulness in leading to a particular result, the latter refers to the fact of doing something because it is interesting, enjoyable, challenging, or fun [63]. For example, hotel employees can be extrinsically motivated to perform well through good salaries and promotion opportunities. Complementary, hotel workers can be intrinsically motivated by designing jobs and positions that are interesting for them, so that they will perform well just for the pleasure and enjoyment inherent to their roles.

HPWS offers the opportunity for hospitality firms to directly motivate employees both through extrinsic (e.g., paying rates) and intrinsic incentives (e.g., individual development). Concretely, recent research has found that extrinsic and intrinsic HRM practices are important to meet hospitality employees' career expectations [46]. Similarly, Lundberg et al. [38] found that HRM practices (e.g., wages and training) positively influence workers motivation. Additionally, motivation has been previously linked to job satisfaction [42,64], suggesting that highly motivated employees will also be satisfied employees. Therefore, it is reasonable to expect that HPWS can have a positive effect on workers' motivation, which will end up enhancing job satisfaction. Consequently, we submit that:

Hypothesis 3: HPWS positively influence hospitality workers' motivation (a), which will, in turn, improve their job satisfaction (b).

\subsection{HPWS, Organizational Commitment, and Job Satisfaction}

In this manuscript, we argue that HPWS impact workers' job satisfaction through an increase in their psychological sense of belonging to their organizations (i.e., organizational commitment), which will directly affect workers' QoL. Employees' organizational commitment refers to the psychological attachment to workplaces that results in a sense of belonging to their firms $[65,66]$. It has been a central issue in the hospitality management literature, because it can counter high levels of employees' intention to leave their jobs, absenteeism, and staff turnover $[67,68]$. Concretely, employees' low organizational commitment positively correlates with high turnover, which increases costs and reduces the quality of provided service, thus negatively impacting client satisfaction and financial performance $[43,49,69]$. Organizational commitment is also positively related with citizen- 
ship behaviors [22] and higher levels of performance [70], highlighting its importance in hospitality management.

Research suggests that managing the work experience after recruitment may be the best antecedent to improve employees' organizational commitment [71]. In their meta analytic review, Meyer and coauthors [71] recommend HPWS as a way of showing organizations' own commitment to their employees, so that workers will feel supported by their firms, enhancing their levels of commitment. Empirical evidence suggests that employees' perceptions of practices such as training, career development, or performance appraisal positively affect their attachment to the places they work in [39]. Moreover, there is wide support for the positive effects of HPWS on employees' commitment [17,22,72]. This is not surprising given the fact that HPWS prepare employees for long-term stays in organizations, which might create a reciprocal bond compared to organizations that lack such HRM practices. For example, recipients of HPWS, which enhance employment stability and career paths by encouraging internal mobility to higher positions, may feel that their hotel supports and cares about them, and consequently, they will not want to find another job.

It is not clear yet if organizational commitment leads to job satisfaction or the opposite. However, most empirical studies correlate both variables [67]. Under the assumption that commitment is an antecedent of job satisfaction, employees' make sense of their situation inside their firms and develop an attitude according to their levels of commitment [73]. In this research, and similar to other studies, we consider that job satisfaction is an outcome of organizational commitment $[43,74]$. Consequently, based on the abovementioned arguments, it is reasonable to expect that HPWS increase employees' attachment to the hotels they work in, resulting in higher levels of job satisfaction. Stated formally, we hypothesize that:

Hypothesis 4: HPWS positively influence hospitality workers' organizational commitment (a), which will, in turn, improve their job satisfaction (b).

\subsection{The Relationship between Employee Well-Being and Individual Job Performance}

In hotel settings, individual job performance is key because of the importance of both service quality and client satisfaction in hotel financial results [11,75]. For example, front line employees' high level of job performance will determine the quality of the interactions with tourists, determining their levels of satisfaction. Workers performing at suboptimal levels would deliver services of lower quality, thus negatively affecting tourist satisfaction. Therefore, enhancing hotel workers' individual job performance is crucial for hoteliers in order to succeed, due to employees' key role in shaping tourists' experiences. We argue that employees' job satisfaction and QoL will positively affect individual job performance.

Examining how to improve employees' QoL is relevant in the hospitality industry, and it may be the key for employees to work with positive attitudes and not quit their jobs. Additionally, through the improvement of workers' QoL, hoteliers can enhance the interactions between workers and clients, improve tourist satisfaction, and ultimately enhance hotel financial performance [8].

As for job satisfaction, over several decades, some meta analyses have supported the positive relationship between job satisfaction and performance [33,76]. Concerning hospitality and tourism, although some scholars have previously argued that employees' job satisfaction may not have a direct effect on hotel financial performance $[7,11]$, we stress its importance here as a direct determinant of client satisfaction, which is, in turn, one of the most salient indicators of hotel performance [11]. Research supports that high levels of job satisfaction will result in higher levels of individual job performance $[77,78]$. This is because satisfied workers will put discretionary effort into their tasks to perform well. For example, if the receptionist of a hotel has a high level of job satisfaction, then (s)he likes her/his job. Consequently, interactions with clients would be better, thus enhancing the quality of the service provided, directly affecting tourist satisfaction and ultimately 
organizational performance. To the contrary, if (s)he dislikes it, her/his job satisfaction is low. The quality of the service provided to potential tourists would be worse, and therefore, tourist satisfaction would be compromised, reducing organizational performance.

Hypothesis 5: Hospitality employees' job satisfaction (a) and QoL (b) positively determine individual job performance.

Bearing in mind these rationalities, we have designed a study that investigates employees' perceptions of HPWS, and their relationships with workers' motivation, organizational commitment, and job satisfaction to impact their overall QoL. We also relate workers' job satisfaction and QoL with individual job performance. Figure 1 captures our research model.

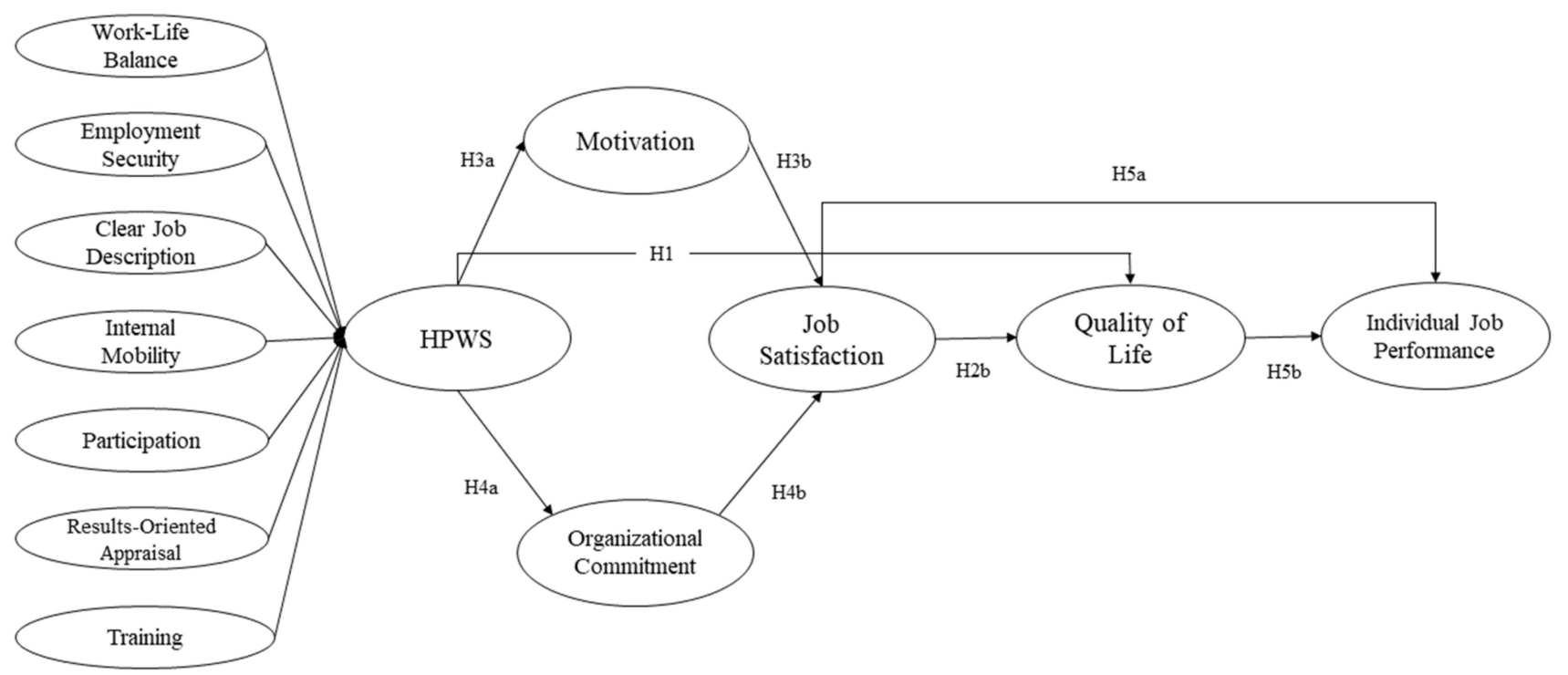

Figure 1. Research model of HPWS effects on employees' well-being and their impact on individual job performance.

\section{Materials and Methods}

As the hotel sector is a central feature of the hospitality industry, this research sets out to test our research hypotheses in hotels in the Canary Islands, a world leading destination that received about 15 million tourists in 2019. We reflect the relevance of this tourism destination for our analysis, with around 90 million overnight stays per year derived from the entry of visitors to the Canary Islands, ranked ninth in Europe, below the United Kingdom, Spain, France, Italy, Germany, Austria, the Netherlands, and Greece and above the other 20 countries that were part of the EU28 before Brexit [79]. More specifically, we conducted a quantitative study through the analysis of self-reported data obtained from a paper-pen questionnaire answered by hotel workers of Tenerife, one of the islands of the archipelago.

\subsection{Data Collection and Sampling Procedure}

We conducted a pilot test with a group of college students majoring in tourism to make sure that items were properly understood and to correct for wording and grammar mistakes. Afterwards, we proceeded with data collection. The authors of this article contacted hotel managers to clarify the research objectives and encouraged participation. Assistants unfamiliar with our objectives were in charge of data collection. Research assistants went into the hotels and provided workers with instructions to fill in the questionnaire. The questionnaire was administered to 494 workers of different hotels ( $57.1 \%$ females and $42.9 \%$ males). Participants were between 20 and 68 years old $(M=41.15 ; S D=9.4 .1)$, and they belonged to different hotel departments ( $25.7 \%$ housekeeping, $14.9 \%$ reception, $24.2 \%$ food 
\& beverage). Concerning their educational level, 50\% had any kind of vocational training or university studies, whereas the other half of surveyed employees had high school or lower educational level. As for their nationality, three quarters were local workers, whereas the rest were foreigners. Most of the workers of our sample worked full time in their hotels $(94 \%)$, and only a small proportion were part-time workers. Almost half of our surveyed workers $(44.5 \%)$ had a salary that ranged from $€ 800-1000$, and $29 \%$ had a salary of about $€ 1000-1200$. Almost $80 \%$ of workers were currently employed by hotels that belonged to a chain of hotels, whereas only $20 \%$ of our sample were employed by independent hotels.

Data collection took place just before the coronavirus crisis, which gives more importance to our research. We placed the focus on three-, four-, and five-star hotels. The questionnaire covered more than one phenomenon in the frame of a research project aimed at enhancing hospitality employees' well-being within their workplaces. In this study, we used measures concerning employees' answers about HPWS, motivation, organizational commitment, job satisfaction, QoL, and individual job performance.

\subsection{Common Method Variance}

We applied both procedural and statistical remedies as recommended by Podsakoff and colleagues [80] to control for common method variance (CMV) when independent and dependent variables are collected from the same source simultaneously. As for procedural techniques during data collection, we assured participants their answers would be anonymous and that there were no right or wrong answers, but that they should answer as honestly as possible, which prevents participants' social desirability bias. As for statistical techniques, we conducted Harman's single factor test, which proves CMV is not a threat when no more than 50 per cent of the total variance is explained by one construct. We subjected all of our measurement items to an exploratory factor analysis using principal components and varimax rotation. The first factor accounted for $42.26 \%$ of the variance assuring CMV was not problematic in our study.

\subsection{Variables and Measures}

We developed a questionnaire to measure all the constructs. Items were selected according to our literature review and discussed by three specialized professors who assured content validity of the measures. Respondents had to rate each item on a fivepoint Likert scale $(1=$ "strongly disagree" and $5=$ "strongly agree"). Higher scores of the measures indicated higher amounts of the constructs.

\subsubsection{HPWS}

We developed a 15-item scale adapting items from similar studies on the topic $[18,20,46]$ to assess the constructs of "employment security" (e.g., my job is guaranteed in this company), "training" (e.g., the company provides training to adapt new employees to their work), "internal mobility" (e.g., the company provides me with real opportunities for promotion and advancement), "results-oriented appraisal" (e.g., the company values my performance at work objectively), "work-life balance" (e.g., my work-life balance is positive), "clear job description" (e.g., my work is well organized, I know what I have to do, and my tasks are well defined) and "participation" (e.g., in my work, I am free to develop my own initiatives and make decisions).

\subsubsection{Motivation}

It was measured with four items typically employed to assess the construct of motivation [81-83]. Example items were "in my work, I am motivated" and "my work is interesting".

\subsubsection{Organizational Commitment}

It was measured with a three-item scale in which participants had to rate their level of agreement with several statements previously used in the literature $[43,65,66]$. Example 
items were "this organization deserves my loyalty" and "I feel a strong sense of belonging to this organization".

\subsubsection{Job Satisfaction}

We developed a three-item scale combining items used in extant research $[7,43]$. Example items included "overall, I am satisfied with my job at this hotel" and "In general, I like working here".

Quality of Life. It was measured with a three-item scale adapting items from other studies $[47,84]$. Example of the items were "I am satisfied with my life" and "I am generally happy with my life",

\subsubsection{Individual Job Performance}

It was measured with three items previously used in the literature $[85,86]$. The scale included items such as "I think I perform most of my tasks effectively" and "I usually perform better than expected".

\subsubsection{Control Variables}

We controlled for participants' age (treated as a continuous variable), gender (coded as a dummy variable 1 = "male", 2 = "female"), and educational level ( 1 = "without studies" and $10=$ "PhD").

\subsection{Statistical Analysis}

We tested our hypotheses through structural equation modelling (SEM) because our aim was to analyze relationships between latent and observed variables. From the different existing SEM techniques, PLS-SEM was performed with the SmartPLS software. The PLS-SEM technique is based on variances, and its purpose is to predict the latent variables by combining principal component analysis and OLS regressions. Following recent recommendations [87] PLS-SEM was chosen for the following reasons: (1) the sample is not excessively large $(\mathrm{N}=494)$, and PLS-SEM works well with limited sample sizes; (2) the distribution of the data is nonnormal, and PLS-SEM does not make any specific assumptions about distributions; and (3) the proposed model includes formative constructs (i.e., HPWS). In line with previous research, HPWS was treated as a "reflectiveformative" higher-order component [88]. This means that several underlying dimensions that are distinct in nature (i.e., different HRM practices), are combined into the higher-order construct of HPWS.

We used the $G^{*}$ Power software [89] to determine the minimum sample size required to carry out our analysis with the PLS-SEM technique. The following parameters were introduced: 0.8 for the power test [90], and 0.15 for the effect size (f2) [89]. Results of the power test indicated that the minimum sample size was 139 cases, concluding that our sample $(\mathrm{N}=494)$ was acceptable to perform PLS-SEM.

\section{Results}

The analysis and interpretation of a statistical model throughout PLS-SEM requires a two-stage approach. The first stage concerns the validation of the measurement model, whereas the second stage refers to the analysis of the structural model [91]. However, given the fact that the proposed model includes a multidimensional, reflective-normative construct (i.e., HPWS) whose dimensions did not have the same number of indicators [92], it was necessary to follow the two-step approach [93].

\subsection{Measurement Model}

To validate the measurement model, which included the aforementioned multidimensional construct, firstly, the first-order model was analyzed. All indicators in this model were reflective. Therefore, reliability (both individual and composite) and validity (both convergent and discriminant) were examined. 
First, to assess individual reliability, we observed all indicator loadings in their corresponding constructs. All of them exceeded the 0.708 threshold established by the literature [86], thus assuring that all indicators represented, at least, $50 \%$ of the construct variance.

The next step consisted in analyzing the reliability of each construct. We followed the composite reliability (CR) criterion, considered a better reliability measure than Cronbach's alpha [94]. In all cases, CR values were higher than the 0.7 threshold established by Nunnally and Bernstein [95]. For better robustness, Dijkstra-Henseler's rho $(\rho \mathrm{A})$ was also analyzed. All values were higher or very close to 0.7 [96]. Therefore, we provide evidence that the first-order measurement scales were reliable.

Next, we examined each construct convergent validity, observing their average variance extracted (AVE). According to Hair et al., [87], AVE values should be higher than 0.5. All constructs exceeded this threshold, which means that each construct explains, at least, $50 \%$ of the variance of its indicators. Table 1 shows the results of both reliability and convergent validity analyses.

Table 1. First-order measurement model: reliability and convergent validity.

\begin{tabular}{|c|c|c|c|c|}
\hline Construct/Indicators & Loading & CR & $\rho \mathrm{A}$ & AVE \\
\hline $\begin{array}{l}\text { Organizational } \\
\text { Commitment }\end{array}$ & & 0.933 & 0.892 & 0.822 \\
\hline COM1 & $0.915^{* * *}$ & & & \\
\hline COM2 & $0.911^{* * *}$ & & & \\
\hline COM3 & $0.893 * * *$ & & & \\
\hline Motivation & & 0.855 & 0.807 & 0.597 \\
\hline MOT1 & $0.737^{* * * *}$ & & & \\
\hline MOT2 & $0.821^{* * *}$ & & & \\
\hline МOT3 & $0.768^{* * * *}$ & & & \\
\hline MOT4 & $0.762^{* * * *}$ & & & \\
\hline Individual Job Performance & & 0.819 & 0.692 & 0.602 \\
\hline PER1 & $0.828^{* * *}$ & & & \\
\hline PER2 & $0.730 * * *$ & & & \\
\hline PER3 & $0.766^{* * * *}$ & & & \\
\hline QoL & & 0.937 & 0.900 & 0.832 \\
\hline QOL1 & $0.916 * * *$ & & & \\
\hline QOL2 & $0.902 * * *$ & & & \\
\hline QOL3 & $0.918^{* * *}$ & & & \\
\hline Job Satisfaction & & 0.936 & 0.899 & 0.831 \\
\hline SAT1 & $0.924 * * *$ & & & \\
\hline SAT2 & $0.923^{* * * *}$ & & & \\
\hline SAT3 & $0.887^{* * * *}$ & & & \\
\hline Work-Life Balance & & 0.902 & 0.858 & 0.755 \\
\hline BAL1 & $0.813^{* * *}$ & & & \\
\hline BAL2 & $0.902 * * *$ & & & \\
\hline BAL3 & $0.889^{* * *}$ & & & \\
\hline Employment Security & & 0.902 & 0.808 & 0.822 \\
\hline SEC1 & $0.926 * * *$ & & & \\
\hline SEC2 & $0.887^{* * *}$ & & & \\
\hline Clear Job Description & & 1.000 & 1.000 & 1.000 \\
\hline CLE1 & $1.000^{* * *}$ & & & \\
\hline Internal Mobility & & 0.905 & 0.850 & 0.760 \\
\hline MOB1 & $0.886^{* * * *}$ & & & \\
\hline MOB2 & $0.896^{* * * *}$ & & & \\
\hline MOB3 & $0.832 * * *$ & & & \\
\hline
\end{tabular}


Table 1. Cont.

\begin{tabular}{ccccc}
\hline Construct/Indicators & Loading & CR & $\boldsymbol{\rho A}$ & AVE \\
\hline Participation & & 0.877 & 0.796 & 0.705 \\
PAR1 & $0.774^{* * *}$ & & & \\
PAR2 & $0.890^{* * *}$ & & & \\
PAR3 & $0.850^{* * *}$ & & 1.000 & 1.000 \\
RES1 & $1.000^{* * *}$ & 1.000 & & 0.867 \\
Training & & 0.929 & & \\
TRA1 & $0.935^{* * *}$ & & & \\
TRA2 & $0.927^{* * *}$ & &
\end{tabular}

To complete the assessment of the first-order measurement model, we analyzed its discriminant validity following Fornell and Lacker's criterion [94]. As can be seen in Table 2, the square root of the AVE of each construct (see the diagonal in italics in Table 2) was higher than the correlations between the other constructs. Complementarily, the HTMT (i.e., the ratio between the heterotrait-monotrait correlations) were below 0.9 providing evidence of discriminant validity [97]. Therefore, the proposed model had discriminant validity (i.e., constructs were different from each other). Table 2 shows the results of our discriminant validity analysis.

Table 2. First-order measurement model: discriminant validity.

\begin{tabular}{|c|c|c|c|c|c|c|c|c|c|c|c|c|}
\hline \multicolumn{13}{|c|}{ Fornell and Larcker's criterion } \\
\hline & $\mathrm{COM}$ & MOT & PER & QOL & SAT & BAL & SEC & CLE & MOB & PAR & RES & TRA \\
\hline $\mathrm{COM}$ & 0.907 & & & & & & & & & & & \\
\hline MOT & 0.690 & 0.772 & & & & & & & & & & \\
\hline PER & 0.417 & 0.502 & 0.776 & & & & & & & & & \\
\hline QOL & 0.427 & 0.459 & 0.420 & 0.912 & & & & & & & & \\
\hline SAT & 0.802 & 0.725 & 0.390 & 0.513 & 0.911 & & & & & & & \\
\hline BAL & 0.559 & 0.514 & 0.425 & 0.501 & 0.616 & 0.869 & & & & & & \\
\hline SEC & 0.514 & 0.467 & 0.347 & 0.337 & 0.552 & 0.437 & 0.907 & & & & & \\
\hline CLE & 0.446 & 0.514 & 0.341 & 0.304 & 0.497 & 0.450 & 0.346 & 1.000 & & & & \\
\hline MOB & 0.585 & 0.559 & 0.289 & 0.348 & 0.634 & 0.473 & 0.665 & 0.339 & 0.872 & & & \\
\hline PAR & 0.573 & 0.635 & 0.368 & 0.388 & 0.639 & 0.572 & 0.425 & 0.487 & 0.513 & 0.840 & & \\
\hline RES & 0.538 & 0.485 & 0.317 & 0.310 & 0.571 & 0.423 & 0.335 & 0.296 & 0.561 & 0.448 & 1.000 & \\
\hline TRA & 0.536 & 0.480 & 0.226 & 0.280 & 0.491 & 0.407 & 0.401 & 0.277 & 0.628 & 0.494 & 0.504 & 0.931 \\
\hline \multicolumn{13}{|c|}{ HTMT } \\
\hline & $\mathrm{COM}$ & MOT & PER & QOL & SAT & BAL & SEC & CLE & MOB & PAR & RES & TRA \\
\hline \multicolumn{13}{|l|}{$\mathrm{COM}$} \\
\hline MOT & 0.809 & & & & & & & & & & & \\
\hline PER & 0.524 & 0.685 & & & & & & & & & & \\
\hline QOL & 0.475 & 0.546 & 0.533 & & & & & & & & & \\
\hline SAT & 0.896 & 0.839 & 0.490 & 0.570 & & & & & & & & \\
\hline BAL & 0.641 & 0.600 & 0.558 & 0.572 & 0.698 & & & & & & & \\
\hline SEC & 0.607 & 0.574 & 0.469 & 0.398 & 0.652 & 0.532 & & & & & & \\
\hline CLE & 0.472 & 0.573 & 0.402 & 0.321 & 0.525 & 0.486 & 0.388 & & & & & \\
\hline MOB & 0.671 & 0.658 & 0.381 & 0.397 & 0.725 & 0.554 & 0.806 & 0.367 & & & & \\
\hline PAR & 0.680 & 0.782 & 0.486 & 0.460 & 0.760 & 0.697 & 0.539 & 0.549 & 0.630 & & & \\
\hline RES & 0.570 & 0.515 & 0.389 & 0.327 & 0.603 & 0.457 & 0.377 & 0.296 & 0.613 & 0.504 & & \\
\hline TRA & 0.617 & 0.557 & 0.299 & 0.320 & 0.564 & 0.477 & 0.495 & 0.301 & 0.747 & 0.602 & 0.547 & \\
\hline
\end{tabular}

COM: Organizational Commitment; MOT: Motivation; PER: Individual Job Performance; QoL: Quality of Life; SAT: Job Satisfaction; BAL: Work-Life Balance; SEC: Employment security; CLE: Clear Job Description; MOB: Internal Mobility; PAR: Participation; RES: Results-Oriented Appraisal; TRA: Training. The diagonal in italics refers to the square root of the AVE of each construct. 
Following the two-step approach, we grouped indicators of each dimension in order to model the second-order construct (i.e., HPWS). Thus, we specified dimensions as latent variables, and their scores were used as indicators of the second-order construct [93]. As HPWS is a reflective-formative construct, we examined all formative factors for multicollinearity paying attention to the variance inflation factors (VIF). All VIF values were lower than the upper threshold of $3 \mathrm{~m}$ suggesting lack of collinearity problems [87]. Additionally, the weights of all the indicators were statistically significant, and therefore, all of them were maintained [91]. Results are shown in Table 3

Table 3. Second-order measurement model.

\begin{tabular}{cccc}
\hline HPWS Dimensions & Loading & Weight & VIF \\
\hline BAL & 0.784 & $0.265^{* * *}$ & 1.731 \\
SEC & 0.681 & $0.169^{* * *}$ & 1.915 \\
CLE & 0.642 & $0.186^{* * *}$ & 1.415 \\
MOB & 0.778 & $0.162^{* *}$ & 2.830 \\
PAR & 0.815 & $0.282^{* * *}$ & 1.924 \\
RES & 0.698 & $0.218^{* * *}$ & 1.640 \\
TRA & 0.654 & $0.076^{* *}$ & 1.842 \\
\hline
\end{tabular}

Note: $\mathrm{n}=10,000$ subsamples; ${ }^{* * *} p$-value $<0.001 ;{ }^{* *} p$-value $<0.05$.

Regarding the discriminant validity of the second-order model, both the Fornell and Larcker and the HTMT criteria were complied with (see Table 4).

Table 4. Second-order measurement model: discriminant validity.

\begin{tabular}{|c|c|c|c|c|c|c|c|c|c|c|c|c|}
\hline \multicolumn{7}{|c|}{ Fornell and Larcker's Criterion } & \multicolumn{6}{|c|}{ HTMT } \\
\hline & COM & HPWS & MOT & PER & QOL & SAT & $\mathrm{COM}$ & HPWS & MOT & PER & QOL & SAT \\
\hline $\mathrm{COM}$ & 0.906 & & & & & & & & & & & \\
\hline HPWS & 0.733 & & & & & & & & & & & \\
\hline MOT & 0.691 & 0.723 & 0.772 & & & & 0.809 & & & & & \\
\hline PER & 0.471 & 0.472 & 0.502 & 0.776 & & & 0.524 & & 0.685 & & & \\
\hline QOL & 0.427 & 0.501 & 0.460 & 0.420 & 0.912 & & 0.475 & & 0.546 & 0.533 & & \\
\hline SAT & 0.802 & 0.794 & 0.726 & 0.390 & 0.513 & 0.911 & 0.896 & & 0.839 & 0.490 & 0.570 & \\
\hline
\end{tabular}

COM: Organizational Commitment; HPWS: High Performance Work Systems; MOT: Motivation; PER: Individual Job Performance; QoL: Quality of Life; SAT: Job Satisfaction. In italics the square root of the AVE.

\subsection{Structural Model}

Before analyzing the structural model, it was necessary to examine whether there were collinearity problems between the antecedent variables of each endogenous construct. The VIF values of the model, again, must be below 3. Results in Table 5 show that there were no collinearity problems.

The assessment of the structural model, which indicates its predictive capacity, requires the examination of three elements: path coefficients, $\mathrm{R}^{2}$ determination coefficients (explained variance), and $\mathrm{Q}^{2}$ values (cross-validated redundancy) [87].

With regards to the predictive power of the model, represented by $\mathrm{R}^{2}$ values, the literature establishes that values of $0.75,0.50$, and 0.25 represent substantial, moderate, and low power [86]. Results show that the proposed model substantially predicts job satisfaction, as its $\mathrm{R}^{2}$ value is 0.749 (see Figure 2). That is, the model explains almost $75.0 \%$ of the variance of job satisfaction. At the same time, organizational commitment and motivation show moderate values $\left(R^{2}=0.537\right.$ and $R^{2}=0.523$, respectively), and QoL shows a low value $\left(\mathrm{R}^{2}=0.287\right)$, which makes sense as QoL is the result of satisfaction in several life domains besides work. Lastly, although the $\mathrm{R}^{2}$ value of individual job performance is below the 0.25 cut point, it is very close to it $\left(R^{2}=0.218\right)$. Therefore, it can be stated that the model also predicts this latter construct. 
Table 5. Structural model assessment.

\begin{tabular}{cccccc}
\hline \multirow{2}{*}{ Relationships } & \multirow{2}{*}{ Path Coefficient $(\boldsymbol{\beta})$} & $\boldsymbol{t}$ & \multicolumn{2}{c}{ Confidence Interval } & \multirow{2}{*}{ VIF } \\
\cline { 4 - 5 } & & & $\mathbf{5 \%}$ & $\mathbf{9 5 \%}$ & \\
\hline HPWS -> QOL & $0.254^{* * *}$ & 3.630 & 0.145 & 0.376 & 2.705 \\
HPWS -> SAT & $0.362^{* * *}$ & 7.602 & 0.283 & 0.440 & 2.681 \\
SAT -> QOL & $0.311^{* * *}$ & 3.915 & 0.174 & 0.435 & 2.705 \\
HPWS -> MOT & $0.723^{* * *}$ & 31.181 & 0.688 & 0.764 & 1.000 \\
MOT -> SAT & $0.177^{* * *}$ & 3.929 & 0.105 & 0.253 & 2.378 \\
HPWS -> COM & $0.733^{* * *}$ & 28.550 & 0.692 & 0.776 & 1.000 \\
COM -> SAT & $0.415^{* * *}$ & 8.408 & 0.331 & 0.494 & 2.448 \\
SAT -> PER & $0.237^{* * *}$ & 3.342 & 0.117 & 0.350 & 1.357 \\
QOL -> PER & $0.299^{* * *}$ & 4.424 & 0.193 & 0.415 & 1.357 \\
\hline
\end{tabular}

Note: $\mathrm{n}=10,000$ subsample; ${ }^{* * *} p$-value < 0.001. COM: Organizational Commitment; HPWS: High Performance Work Systems; MOT: Motivation; PER: Individual Job Performance; QoL: Quality of Life; SAT: Job Satisfaction.

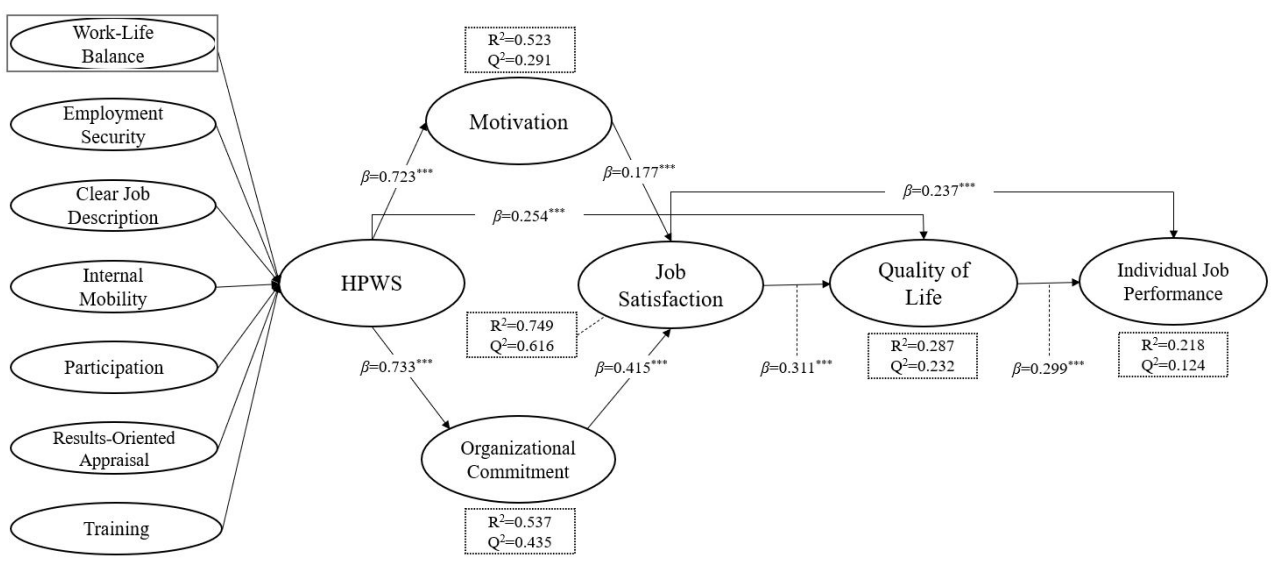

Figure 2. Results of the structural relationships among the study constructs. ${ }^{* * *} p$-value $\left.<0.001\right)$.

The $\mathrm{Q}^{2}$ cross-validated redundancy values explain the model's predictive relevance. To be satisfactory, $\mathrm{Q}^{2}$ values must be higher than 0 [91]. In the proposed model, all $\mathrm{Q}^{2}$ values complied this condition (see Figure 2).

Finally, regarding our hypotheses testing, we provide evidence to accept all of them, as the proposed relationships between constructs are statistically significant and follow the stated direction. Thus, HPWS positively influences QoL (H1), job satisfaction (H2a), motivation (H3a), and organizational commitment (H4a). Job satisfaction positively influences QoL ( $\mathrm{H} 2 \mathrm{~b})$ and individual job performance ( $\mathrm{H} 5 \mathrm{a})$, and it is simultaneously influenced by workers' motivation ( $\mathrm{H} 3 \mathrm{~b}$ ) and organizational commitment (H4b). Lastly, QoL positively influences individual job performance (H5b) (see both Table 5 and Figure 2).

\section{Discussion}

We (1) provide the field with empirical evidence that further supports the benefits of HPWS in hotels to enhance workers' outcomes, (2) explore several paths through which HPWS impact employees' well-being, and (3) empirically test the direct positive repercussions of employees' job satisfaction and QoL on individual job performance.

\subsection{Theoretical Contributions}

Concerning our first major contribution, we complement existing evidence that highlighted the importance of HPWS for the hotel sector in order to increase hotel performance [26] or reduce employee turnover $[18,19,98]$. Concretely, we provided evidence of their direct positive effects on employees' outcomes (i.e., direct enhancement of employees' motivation, organizational commitment, job satisfaction, and QoL). In line with other studies, we support the positive effects of HPWS on employees' job satisfaction [17,45] and 
make these findings generalizable to the accommodation industry. Likewise, we have also provided further support on the positive relationship between HPWS and QoL.

Regarding our second major contribution, this paper heeds the urgent call from several scholars to investigate the inside of the so-called black box [18] that relates HPWS to outcomes. For example, previous research found that organizational commitment and job satisfaction were mediators linking HPWS with department performance and resignation intention [23]. In our research, we found causality from HPWS through organizational commitment and then job satisfaction to enhance QoL. We further revealed the underlying mechanisms inside the black box supporting the parallel causal chain through which the effect of HPWS transfers through both workers' motivation and job satisfaction to enhance employees' QoL.

As for our third major contribution, this paper widens our current knowledge of how hoteliers can encourage higher levels of performance. Although the importance of human resources for hospitality and tourism enterprises has been widely acknowledged in the existing literature $[8,14]$, the extent to which employees' well-being affects performance still remains controversial. Regarding this, most of the available evidence places the focus on workers' job satisfaction. Along these lines, our results may very well explain why several other scholars have found no relationship between workers' job satisfaction and hotel performance $[7,11]$. We align with previous studies supporting that job satisfaction determines individual job performance [78], which is the most important predictor of client satisfaction, which will ultimately enhance hotel performance. In this study, we also highlight the importance of employees' overall QoL. Whereas few available findings have focused on how to enhance workers' QoL as an end in itself [47], we further support the importance of doing this because of its direct effect on individual job performance.

\subsection{Managerial Recommendations}

This study is helpful to managers of hospitality companies in planning and executing HRM practices. Findings demonstrate that hotel managers and HR specialists should adopt HPWS as a means of obtaining outcomes regarding employees' attitudes and behaviors. HPWS can also enhance hotel employee retention [19], but our results provide evidence on their effects to improve both employees' well-being and job performance. Consequently, we encourage hoteliers to invest in the wide range of practices that comprise HRM systems [18] in order to satisfy and retain their workforce.

Indeed, not only do we recommend the design of proper systems of HRM practices, but also an efficient and effective implementation of them, as workers' perceptions of such practices will determine their levels of motivation, commitment, satisfaction, and overall QoL. In light of these considerations, we suggest managers overtly communicate the HPWS in use so that employees become more aware of them and the job environment in which they are working [22].

\subsection{Limitations and Directions for Future Research}

Despite the valuable contribution of our findings, results must be interpreted cautiously against the backdrop of several limitations that deserve attention in future studies. First, our design involved collecting data from a sample of hotel employees to make our results generalizable for the whole hospitality sector. However, it may be true that HPWS effects on employees' outcomes differ across departments (e.g., housekeeping, kitchen, food and beverage, front office, etc.). Consequently, future research could consider a design to test the relationships found here in different groups of workers [29], so that hoteliers could prioritize investments in HPWS by departments. In line with this, we also want to acknowledge that workers' perceptions may very well differ across managerial levels. Therefore, another variable to bear in mind in future studies would be the managerial level or the expertise of the respondents. Consequently, future research designs should ask respondents about tenure in the company and also the managerial position of respondents, 
and the proven relationships here should be tested, bearing in mind the moderating effects that both variables may exert over the paths found in our study.

Second, we deliberately decided to analyze measures of employees' well-being and individual job performance, but there may be other individual-level indicators that remain unexplored in the hotel sector. In this sense, we encourage future research to investigate the relationship between HPWS and absenteeism [45] or employees' effort [29]. In addition, there may be other team- or organizational-level dependent variables of interest such as departmental performance [17]. Scholars could consider if HPWS can enhance specific departments' performance (e.g., front office, housekeeping, food and beverage) or even compare the effects by testing moderation hypotheses.

Third, in line with similar studies on the topic, we relied on self-reported measures [22]; however, future research could consider alternative sources of information. For example, in order to rate individual performance, an alternative source of information would be the rating of supervisors. Similarly, alternative measures such as absenteeism could be gathered from the HR department.

Fourth, our data collection was carried out before the coronavirus pandemic; thus, it is one of the most recent analyses with hotel workers before the pandemic. Once hospitality activity recovers from its sharp decrease, it will be interesting to compare if the relationships found here hold true.

Fifth, we would like to acknowledge that there may be other variables such as team leadership or corporate culture that may very well impact on the employees' attitudes highlighted in our study. Concretely, team leadership has been widely accepted as a process with the capability of influencing employees' attitudes and behaviors such as their motivation [99]. In fact, we propose future studies to analyze the relationships found here, testing the moderating effects based on the differential impacts that various leadership styles are able to exert on employees' attitudinal, behavioral, and cognitive outcomes [100].

Sixth, our data collection took place in one island of the archipelago. Although we intended to collect a representative sample so that findings here could be generalizable for the lodgment industry, we recommend carrying out future studies in other destinations to corroborate that the relationships found here hold true independently of the context in which the hotels operate.

\section{Conclusions}

Our research highlights the importance of HPWS on several employees' attitudinal and behavioral outcomes. First, we provided evidence that HPWS are conducive to increase employees' motivation, organizational commitment, and job satisfaction, which have been previously highlighted as relevant variables conducive for higher levels of performance [101]. Second, our research also highlights the importance of HPWS on employees' QoL. Third, we shed light on the mechanisms linking HPWS with employees' outcomes, pointing out the relevance of causal chains of effects through which HPWS can ultimately impact performance. Fourth, our research also links employees' well-being with performance, which has been an under-researched topic in hospitality and tourism.

As a closing note, further investigation on HPWS may very well contribute to aligning the hospitality industry with the promotion of decent work encouraged in the Sustainable Development Goal 8 [6]. That is, HPWS are conducive to increased levels of employees' job satisfaction and overall QoL, which determine their individual job performance. Thus, by providing workers with a better work environment, hoteliers can increase their workforce performance, which will ultimately improve tourist satisfaction and organizational performance. We hope this research is found useful by practitioners and scholars, and that future studies on this topic will be carried out, especially in a context of the health and economic crisis that is making the industry fight for its survival.

Author Contributions: Conceptualization: D.D.-A., M.G.-d.-1.-R., and F.J.G.-R.; methodology: D.D.-A. and L.R.-D.; formal analysis: L.R.-D. and D.D.-A.; investigation: D.D.-A., M.G.-d.-1.-R., F.J.G.-R., and L.R.-D.; resources: F.J.G.-R. and M.G.-d.-1.-R.; data curation: L.R.-D. and D.D.-A.; writing-original 
draft preparation: D.D.-A.; writing—review and editing: D.D.-A., M.G.-d.-1.-R., F.J.G.-R., and L.R.-D.; supervision: M.G.-d.-1.-R. and F.J.G.-R.; project administration: D.D.-A. and M.G.-d.-1.-R.; funding acquisition: F.J.G.-R. and M.G.-d.-1.-R. All authors have read and agreed to the published version of the manuscript.

Funding: This research was funded by Fundación CajaCanarias, grant number 2016TUR14.

Institutional Review Board Statement: Ethical review and approval were waived for this study because respondents' anonymous and confidential responses were assured.

Informed Consent Statement: All participants took part in our research voluntarily and they cannot be identified in any way. They provided informed consent by agreeing to take part in our survey.

Data Availability Statement: The data presented in this study are available on request from the corresponding author.

Conflicts of Interest: The authors declare no conflict of interest.

\section{References}

1. UNWTO. Impact Assessment of the COVID-19 Outbreak on International Tourism, 5 March 2020. Updated Assessment 27 March 2020. Available online: https:/ / www.unwto.org/impact-assessment-of-the-covid-19-outbreak-on-international-tourism (accessed on 6 January 2021).

2. ILO. Guidelines on Decent Work and Socially Responsible Tourism 2017; International Labour Office, Sectoral Policies DepartmentILO: Geneva, Switzerland, 2017. Available online: https:/ /www.ilo.org/wcmsp5/groups/public/---ed_dialogue/---sector/ documents/normativeinstrument/wcms_546337.pdf (accessed on 8 January 2021).

3. Zhao, X.R.; Ghiselli, R.; Law, R.; Ma, J. Motivating Frontline Employees: Role of Job Characteristics in Work and Life Satisfaction. J. Hosp. Tour. Manag. 2016, 27, 27-38. [CrossRef]

4. OECD. Tackling Coronavirus (COVID-19): Tourism Policy Responses. 2020. Available online: https://www.oecd.org/coronavirus/ policy-responses/tourism-policy-responses-to-the-coronavirus-covid-19-6466aa20/ (accessed on 15 January 2021).

5. ILO COVID-19 and the World of Work. 2020. Available online: https://www.ilo.org/wcmsp5/groups/public/---dgreports/--dcomm/documents/briefingnote/wcms_767028.pdf (accessed on 28 January 2021).

6. United Nations. Transforming Our World: The 2030 Agenda for Sustainable Development; United Nations, Department of Economic and Social Affairs: New York, NY, USA, 2015. Available online: https://www.un.org/ga/search/view_doc.asp?symbol=A/RES/ 70/1\&Lang=E (accessed on 20 January 2021).

7. Chi, C.G.; Gursoy, D. Employee satisfaction, customer satisfaction, and financial performance: An empirical examination. Int. J. Hosp. Manag. 2009, 28, 245-253. [CrossRef]

8. Kusluvan, S.; Kusluvan, Z.; Ilhan, I.; Buyruk, L. The Human Dimension: A Review of Human Resources Management Issues in the Tourism and Hospitality Industry. Cornell Hosp. Q. 2010, 51, 171-214. [CrossRef]

9. Tang, T.-W.; Tang, Y.-Y. Promoting service-oriented organizational citizenship behaviors in hotels: The role of high-performance human resource practices and organizational social climates. Int. J. Hosp. Manag. 2012, 31, 885-895. [CrossRef]

10. Tracey, J.B. A review of human resources management research. Int. J. Contemp. Hosp. Manag. 2014, 26, 679-705. [CrossRef]

11. Kim, W.G.; Cho, M.; Brymer, R.A. Determinants Affecting Comprehensive Property-Level Hotel Performance: The Moderating Role of Hotel Type. Int. J. Hosp. Manag. 2013, 34, 404-412. [CrossRef]

12. UNWTO. Sustainable Tourism for Development Guidebook—Enhancing Capacities for Sustainable Tourism for Development in Developing Countries; UNWTO: Madrid, Spain, 2013.

13. Baum, T. Human Resource Management for Tourism, Hospitality and Leisure: An International Perspective; Thomson Learning: London, UK, 2006; ISBN 1-84480-196-9.

14. Baum, T. Human Resources in Tourism: Still Waiting for Change?-A 2015 Reprise. Tour. Manag. 2015, 50, 204-212. [CrossRef]

15. Baum, T.; Kralj, A.; Robinson, R.N.; Solnet, D.J. Tourism Workforce Research: A Review, Taxonomy and Agenda. Ann. Tour. Res. 2016, 60, 1-22. [CrossRef]

16. Øgaard, T.; Marnburg, E.; Larsen, S. Perceptions of Organizational Structure in the Hospitality Industry: Consequences for Commitment, Job Satisfaction and Perceived Performance. Tour. Manag. 2008, 29, 661-671. [CrossRef]

17. Messersmith, J.G.; Patel, P.C.; Lepak, D.P.; Gould-Williams, J.S. Unlocking the black box: Exploring the link between highperformance work systems and performance. J. Appl. Psychol. 2011, 96, 1105-1118. [CrossRef]

18. Sun, L.-Y.; Aryee, S.; Law, K.S. High-Performance Human Resource Practices, Citizenship Behavior, and Organizational Performance: A Relational Perspective. Acad. Manag. J. 2007, 50, 558-577. [CrossRef]

19. Wong, I.A.; Xu, S.; Chan, S.H.G.; He, M. A cross-level investigation of the role of human resources practices: Does brand equity matter? Tour. Manag. 2019, 75, 418-426. [CrossRef]

20. Delery, J.E.; Doty, D.H. Modes of Theorizing in Strategic Human Resource Management: Tests of Universalistic, Contingency, and Configurational Performance Predictions. Acad. Manag. J. 1996, 39, 802-835. [CrossRef] 
21. Huselid, M.A. The Impact of Human Resource Management Practices on Turnover, Productivity, and Corporate Financial Performance. Acad. Manag. J. 1995, 38, 635-672.

22. Kehoe, R.R.; Wright, P.M. The Impact of High-Performance Human Resource Practices on Employees' Attitudes and Behaviors. J. Manag. 2013, 39, 366-391. [CrossRef]

23. Macky, K.; Boxall, P. The Relationship between 'High-Performance Work Practices' and Employee Attitudes: An Investigation of Additive and Interaction Effects. Int. J. Hum. Resour. Manag. 2007, 18, 537-567. [CrossRef]

24. Cho, S.; Woods, R.H.; Jang, S.S.; Erdem, M. Measuring the Impact of Human Resource Management Practices on Hospitality Firms' Performances. Int. J. Hum. Resour. Manag. 2006, 25, 262-277. [CrossRef]

25. Karatepe, O.M. High-Performance Work Practices and Hotel Employee Performance: The Mediation of Work Engagement. Int. J. Hum. Resour. Manag. 2013, 32, 132-140. [CrossRef]

26. Cheng-Hua, T.; Shyh-Jer, C.; Shih-Chien, F. Employment Modes, High-Performance Work Practices, and Organizational Performance in the Hospitality Industry. Cornell Hosp. Q. 2009, 50, 413-431. [CrossRef]

27. Karatepe, O.M.; Vatankhah, S. The Effects of High-Performance Work Practices and Job Embeddedness on Flight Attendants' Performance Outcomes. J. Air Transp. Manag. 2014, 37, 27-35. [CrossRef]

28. Kloutsiniotis, P.V.; Mihail, D.M. High Performance Work Systems in the Tourism and Hospitality Industry: A Critical Review. Int. J. Contemp. Hosp. Manag. 2020, 32, 2365-2395. [CrossRef]

29. McClean, E.; Collins, C.J. High-commitment HR Practices, Employee Effort, and Firm Performance: Investigating the Effects of HR Practices across Employee Groups within Professional Services Firms. Hum. Resour. Manag. 2011, 50, 341-363. [CrossRef]

30. Alafeshat, R.; Tanova, C. Servant Leadership Style and High-Performance Work System Practices: Pathway to a Sustainable Jordanian Airline Industry. Sustainability 2019, 11, 6191. [CrossRef]

31. Karatepe, O.M.; Olugbade, O.A. The mediating role of work engagement in the relationship between high-performance work practices and job outcomes of employees in Nigeria. Int. J. Contemp. Hosp. Manag. 2016, 28, 2350-2371. [CrossRef]

32. Murphy, K.; Torres, E.; Ingram, W.; Hutchinson, J. A review of high performance work practices (HPWPs) literature and recommendations for future research in the hospitality industry. Int. J. Contemp. Hosp. Manag. 2018, 30, 365-388. [CrossRef]

33. Judge, T.A.; Thoresen, C.J.; Bono, J.E.; Patton, G.K. The Job Satisfaction-Job Performance Relationship: A Qualitative and Quantitative Review. Psychol. Bull. 2001, 127, 376. [CrossRef]

34. Peters, M.; Kallmuenzer, A.; Buhalis, D. Hospitality entrepreneurs managing quality of life and business growth. Curr. Issues Tour. 2019, 22, 2014-2033. [CrossRef]

35. Currivan, D.B. The Causal Order of Job Satisfaction and Organizational Commitment in Models of Employee Turnover. Hum. Resour. Manag. Rev. 1999, 9, 495-524. [CrossRef]

36. Lin, J.-H.; Wong, J.-Y.; Ho, C. Promoting Frontline Employees' Quality of Life: Leisure Benefit Systems and Work-to-Leisure Conflicts. Tour. Manag. 2013, 36, 178-187. [CrossRef]

37. Costen, W.M.; Salazar, J. The Impact of Training and Development on Employee Job Satisfaction, Loyalty, and Intent to Stay in the Lodging Industry. J. Hum. Resour. Hosp. Tour. 2011, 10, 273-284. [CrossRef]

38. Lundberg, C.; Gudmundson, A.; Andersson, T.D. Herzberg's Two-Factor Theory of Work Motivation Tested Empirically on Seasonal Workers in Hospitality and Tourism. Tour. Manag. 2009, 30, 890-899. [CrossRef]

39. Meyer, J.P.; Smith, C.A. HRM Practices and Organizational Commitment: Test of a Mediation Model. Can. J. Adm. Sci./Rev. Can. des Sci. de l'Administration 2000, 17, 319-331. [CrossRef]

40. Bowling, N.A.; Eschleman, K.J.; Wang, Q. A Meta-analytic Examination of the Relationship between Job Satisfaction and Subjective Well-being. J. Occup. Organ. Psychol. 2010, 83, 915-934. [CrossRef]

41. Susskind, A.M.; Borchgrevink, C.P.; Kacmar, K.M.; Brymer, R.A. Customer service employees' behavioral intentions and attitudes: An examination of construct validity and a path model. Int. J. Hosp. Manag. 2000, 19, 53-77. [CrossRef]

42. Arifin, H.M. The Influence of Competence, Motivation, and Organisational Culture to High School Teacher Job Satisfaction and Performance. Int. Educ. Stud. 2015, 8, 38-45. [CrossRef]

43. Zopiatis, A.; Constanti, P.; Theocharous, A.L. Job Involvement, Commitment, Satisfaction and Turnover: Evidence from Hotel Employees in Cyprus. Tour. Manag. 2014, 41, 129-140. [CrossRef]

44. Dhar, R.L. The Effects of High Performance Human Resource Practices on Service Innovative Behaviour. Int. J. Hosp. Manag. 2015, 51, 67-75. [CrossRef]

45. Latorre, F.; Guest, D.; Ramos, J.; Gracia, F.J. High Commitment HR Practices, the Employment Relationship and Job Performance: A Test of a Mediation Model. Eur. Manag. J. 2016, 34, 328-337. [CrossRef]

46. Safavi, H.P.; Karatepe, O.M. High-Performance Work Practices and Hotel Employee Outcomes: The Mediating Role of Career Adaptability. Int. J. Contemp. Hosp. Manag. 2018, 30, 1112-1133. [CrossRef]

47. Kim, H.; Woo, E.; Uysal, M.; Kwon, N. The Effects of Corporate Social Responsibility (CSR) on Employee Well-Being in the Hospitality Industry. Int. J. Contemp. Hosp. Manag. 2018, 30, 1584-1600. [CrossRef]

48. Karatepe, O.M.; Baddar, L. An Empirical Study of the Selected Consequences of Frontline Employees' Work-Family Conflict and Family-Work Conflict. Tour. Manag. 2006, 27, 1017-1028. [CrossRef]

49. Deery, M.; Jago, L. Revisiting Talent Management, Work-Life Balance and Retention Strategies. Int. J. Contemp. Hosp. Manag. 2015, 27, 453-472. [CrossRef] 
50. Hassan, N.; Maamor, H.; Razak, A.; Lapok, F. The Effect of Quality of Work Life (QWL) Programs on Quality of Life (QOL) among Employees at Multinational Companies in Malaysia. Procedia-Soc. Behav. Sci. 2014, 112, $24-34$.

51. Nadiri, H.; Tanova, C. An Investigation of the Role of Justice in Turnover Intentions, Job Satisfaction, and Organizational Citizenship Behavior in Hospitality Industry. Int. J. Hosp. Manag. 2010, 29, 33-41. [CrossRef]

52. Reisel, W.D.; Probst, T.M.; Chia, S.-L.; Maloles, C.M.; König, C.J. The Effects of Job Insecurity on Job Satisfaction, Organizational Citizenship Behavior, Deviant Behavior, and Negative Emotions of Employees. Int. Stud. Manag. Organ. 2010, 40, 74-91. [CrossRef]

53. Scott, K.D.; Taylor, G.S. An Examination of Conflicting Findings on the Relationship between Job Satisfaction and Absenteeism: A Meta-Analysis. Acad. Manag. J. 1985, 28, 599-612.

54. Jang, J.; George, R.T. Understanding the Influence of Polychronicity on Job Satisfaction and Turnover Intention: A Study of Non-Supervisory Hotel Employees. Int. J. Hosp. Manag. 2012, 31, 588-595. [CrossRef]

55. Kong, H.; Jiang, X.; Chan, W.; Zhou, X. Job satisfaction research in the field of hospitality and tourism. Int. J. Contemp. Hosp. Manag. 2018, 30, 2178-2194. [CrossRef]

56. Cain, L.; Busser, J.; Kang, H.J. (Annette) Executive chefs' calling: Effect on engagement, work-life balance and life satisfaction. Int. J. Contemp. Hosp. Manag. 2018, 30, 2287-2307. [CrossRef]

57. Arasli, H.; Nergiz, A.; Yesiltas, M.; Gunay, T. Human Resource Management Practices and Service Provider Commitment of Green Hotel Service Providers: Mediating Role of Resilience and Work Engagement. Sustainability 2020, 12, 9187. [CrossRef]

58. Santero-Sanchez, R.; Segovia-Pérez, M.; Castro-Nuñez, B.; Figueroa-Domecq, C.; Talón-Ballestero, P. Gender Differences in the Hospitality Industry: A Job Quality Index. Tour. Manag. 2015, 51, 234-246. [CrossRef]

59. Iverson, R.D.; Maguire, C. The Relationship between Job and Life Satisfaction: Evidence from a Remote Mining Community. Hum. Relations 2000, 53, 807-839. [CrossRef]

60. Mitchel, T.R. Motivation: New Directions for Theory, Research, and Practice. Acad. Manag. Rev. 1982, 7, 80-88. [CrossRef]

61. Putra, E.D.; Cho, S.; Liu, J. Extrinsic and Intrinsic Motivation on Work Engagement in the Hospitality Industry: Test of Motivation Crowding Theory. Tour. Hosp. Res. 2017, 17, 228-241. [CrossRef]

62. Chang, J.-H.; Teng, C.-C. Intrinsic or Extrinsic Motivations for Hospitality Employees' Creativity: The Moderating Role of Organization-Level Regulatory Focus. Int. J. Hosp. Manag. 2017, 60, 133-141. [CrossRef]

63. Deci, E.L.; Ryan, L.M. Intrinsic Motivation and Self-Determination in Human Behavior; Plenum: New York, NY, USA; London, UK, 1985.

64. Sledge, S.; Miles, A.K.; Coppage, S. What Role Does Culture Play? A Look at Motivation and Job Satisfaction among Hotel Workers in Brazil. Int. J. Hum. Resour. Manag. 2008, 19, 1667-1682. [CrossRef]

65. Allen, N.J.; Meyer, J.P. Affective, Continuance, and Normative Commitment to the Organization: An Examination of Construct Validity. J. Vocat. Behav. 1996, 49, 252-276. [CrossRef]

66. Meyer, J.P.; Allen, N.J.; Smith, C.A. Commitment to Organizations and Occupations: Extension and Test of a Three-Component Conceptualization. J. Appl. Psychol. 1993, 78, 538-551. [CrossRef]

67. Mathieu, J.E.; Zajac, D.M. A Review and Meta-Analysis of the Antecedents, Correlates, and Consequences of Organizational Commitment. Psychol. Bull. 1990, 108, 171. [CrossRef]

68. Subramaniam, N.; McManus, L.; Mia, L. Enhancing Hotel Managers' Organisational Commitment: An Investigation of the Impact of Structure, Need for Achievement and Participative Budgeting. Int. J. Hosp. Manag. 2002, 21, 303-320. [CrossRef]

69. Lam, T.; Lo, A.; Chan, J. New Employees' Turnover Intentions and Organizational Commitment in the Hong Kong Hotel Industry. J. Hosp. Tour. Res. 2002, 26, 217-234. [CrossRef]

70. Kim, H.; Rhou, Y.; Uysal, M.; Kwon, N. An Examination of the Links between Corporate Social Responsibility (CSR) and Its Internal Consequences. Int. J. Hosp. Manag. 2017, 61, 26-34. [CrossRef]

71. Meyer, J.P.; Stanley, D.J.; Herscovitch, L.; Topolnytsky, L. Affective, Continuance, and Normative Commitment to the Organization: A Meta-Analysis of Antecedents, Correlates, and Consequences. J. Vocat. Behav. 2002, 61, 20-52. [CrossRef]

72. Kwon, K.; Bae, J.; Lawler, J.J. High Commitment HR Practices and Top Performers. Manag. Int. Rev. 2010, 50, 57-80. [CrossRef]

73. Bateman, T.S.; Strasser, S. A Longitudinal Analysis of the Antecedents of Organizational Commitment. Acad. Manag. J. 1984, 27, 95-112.

74. Namasivayam, K.; Zhao, X. An Investigation of the Moderating Effects of Organizational Commitment on the Relationships between Work-Family Conflict and Job Satisfaction among Hospitality Employees in India. Tour. Manag. 2007, 28, 1212-1223. [CrossRef]

75. Fantazy, K.A.; Kumar, V.; Kumar, U. Supply Management Practices and Performance in the Canadian Hospitality Industry. Int. J. Hosp. Manag. 2010, 29, 685-693. [CrossRef]

76. Iaffaldano, M.T.; Muchinsky, P.M. Job Satisfaction and Job Performance: A Meta-Analysis. Psychol. Bull. 1985, 97, 251. [CrossRef]

77. Gu, Z.; Siu, R.C.S. Drivers of job satisfaction as related to work performance in Macao casino hotels. Int. J. Contemp. Hosp. Manag. 2009, 21, 561-578. [CrossRef]

78. Schmit, M.J.; Allscheid, S.P. Employee Attitudes and Customer Satisfaction: Making Theoretical and Empirical Connections. Pers. Psychol. 1995, 48, 521-536. [CrossRef]

79. Eurostat Tourism Statistics. Nights Spent at Tourist Accommodation Establishments. 2019. Available online: https://ec.europa.eu/ eurostat/databrowser/view/tour_occ_nim/default/table?lang=en (accessed on 14 March 2021). 
80. Podsakoff, P.M.; MacKenzie, S.B.; Lee, J.-Y.; Podsakoff, N.P. Common Method Biases in Behavioral Research: A Critical Review of the Literature and Recommended Remedies. J. Appl. Psychol. 2003, 88, 879. [CrossRef]

81. Chiang, C.-F.; Jang, S.S. An Expectancy Theory Model for Hotel Employee Motivation. Int. J. Hosp. Manag. 2008, $27,313-322$. [CrossRef]

82. Kuvaas, B. Work performance, affective commitment, and work motivation: The roles of pay administration and pay level. $J$. Organ. Behav. 2006, 27, 365-385. [CrossRef]

83. Westover, J.H. Comparative International Differences in Intrinsic and Extrinsic Job Quality Characteristics and Worker Satisfaction, 1989-2005. Int. J. Bus. Soc. Sci. 2012, 3, 1-16.

84. Zhao, X.R.; Qu, H.; Ghiselli, R. Examining the Relationship of Work-Family Conflict to Job and Life Satisfaction: A Case of Hotel Sales Managers. Int. J. Hosp. Manag. 2011, 30, 46-54. [CrossRef]

85. Karatepe, O.M.; Uludag, O.; Menevis, I.; Hadzimehmedagic, L.; Baddar, L. The Effects of Selected Individual Characteristics on Frontline Employee Performance and Job Satisfaction. Tour. Manag. 2006, 27, 547-560. [CrossRef]

86. Rapp, A.; Baker, T.L.; Bachrach, D.G.; Ogilvie, J.; Beitelspacher, L.S. Perceived Customer Showrooming Behavior and the Effect on Retail Salesperson Self-Efficacy and Performance. J. Retail. 2015, 91, 358-369. [CrossRef]

87. Hair, J.F.; Risher, J.J.; Sarstedt, M.; Ringle, C.M. When to use and how to report the results of PLS-SEM. Eur. Bus. Rev. 2019, 31, 2-24. [CrossRef]

88. Kloutsiniotis, P.V.; Mihail, D.M. The Effects of High Performance Work Systems in Employees' Service-Oriented OCB. Int. J. Hosp. Manag. 2020, 90, 102610. [CrossRef]

89. Faul, F.; Erdfelder, E.; Lang, A.-G.; Buchner, A. G*Power 3: A flexible statistical power analysis program for the social, behavioral, and biomedical sciences. Behav. Res. Methods 2007, 39, 175-191. [CrossRef]

90. Cohen, J. Statistical Power Analysis for the Behavioural Sciences, 2nd ed.; Erbaum Press: Hillsdale, NJ, USA, 1988.

91. Hair, J.F., Jr.; Hult, G.T.M.; Ringle, C.; Sarstedt, M. A Primer on Partial Least Squares Structural Equation Modeling (PLS-SEM); Sage Publications: Thousand Oaks, CA, USA, 2016; ISBN 1-4833-7743-1.

92. Becker, J.-M.; Klein, K.; Wetzels, M. Hierarchical Latent Variable Models in PLS-SEM: Guidelines for Using Reflective-Formative Type Models. Long Range Plan. 2012, 45, 359-394. [CrossRef]

93. Wright, R.T.; Campbell, D.E.; Thatcher, J.B.; Roberts, N. Operationalizing Multidimensional Constructs in Structural Equation Modeling: Recommendations for IS Research. Commun. Assoc. Inf. Syst. 2012, 30, 23. [CrossRef]

94. Fornell, C.; Larcker, D.F. Evaluating Structural Equation Models with Unobservable Variables and Measurement Error. J. Mark. Res. 1981, 18, 39-50. [CrossRef]

95. Nunnally, J.C.; Bernstein, I.H. Psychometric Theory; McGraw-Hill: New York, NY, USA, 1994.

96. Dijkstra, T.K.; University of Groningen; Henseler, J. University of Twente; Universidade Nova de Lisboa Consistent Partial Least Squares Path Modeling. MIS Q. 2015, 39, 297-316. [CrossRef]

97. Henseler, J.; Ringle, C.M.; Sarstedt, M. A new criterion for assessing discriminant validity in variance-based structural equation modeling. J. Acad. Mark. Sci. 2015, 43, 115-135. [CrossRef]

98. Afsar, B.; Shahjehan, A.; Shah, S.I. Frontline Employees' High-Performance Work Practices, Trust in Supervisor, Job-Embeddedness and Turnover Intentions in Hospitality Industry. Int. J. Contemp. Hosp. Manag. 2018, 30, 1436-1452. [CrossRef]

99. Ballesteros-Rodríguez, J.L.; De Saá-Pérez, P.; García-Carbonell, N.; Martín-Alcázar, F.; Sánchez-Gardey, G. The influence of team members' motivation and leaders' behaviour on scientific knowledge sharing in universities. Int. Rev. Adm. Sci. 2020, 1-17. [CrossRef]

100. Dorta-Afonso, D. A Longitudinal Approach to Team Adaptation Through the Two-Phase Framework: The Role of Team Leadership, Coordination, Behavioral Interaction Patterns and Team Cognition on Team Adaptation when Facing Changes of Different Magnitude. Ph.D Thesis, Universidad Autónoma de Madrid, Madrid, Spain, 2019.

101. García-Rodríguez, F.J.; Dorta-Afonso, D.; González-de-la-Rosa, M. Hospitality diversity management and job satisfaction: The mediating role of organizational commitment across individual differences. Int. J. Hosp. Manag. 2020, 91, 102698. [CrossRef] 